\title{
ПСИХОЛОГО-ПЕДАГОГІЧНІ УМОВИ ФОРМУВАННЯ ГОТОВНОСТІ СТУДЕНТІВ ДО ТВОРЧОЇ ПРОФЕСІЙНО-ПЕДАГОГІЧНОӤ ДІЯЛЬНОСТІ
}

Шепеленко Т. Л., Пінська О. Л. Психолого-педагогічні умови формування готовності студентів до творчої професійно-педагогічної діяльності.

У статті розкривається сутність, особливості професійно-педагогічної творчості, готовність студентів до творчої педагогічної діяльності, характеризуються іï структура та компонентний зміст (психологічна, теоретична й практична готовність), висвітлюються психолого-педагогічні умови ефективного формування в навчальному процесі вищої школи.

Ключові слова: готовність, творча педагогічна діяльність, співтворчість, творча ситуація, творчий потенціал.

Шепеленко Т. Л., Пинская Е. Л. Психолого-педагогические условия формирования готовности студентов к творческой профессиональнопедагогической деятельности.

В статье раскрывается сущность, особенности профессиональнопедагогического творчества, готовность студентов к творческой педагогической деятельности, характеризуются ее структура и компонентное содержание (психологическая, теоретическая, практическая готовность), освещаются психологопедагогические условия формирования в учебном процессе высшей школы.

Ключевые слова: готовность, творческая педагогическая деятельность, сотворчество, творческая ситуация, творческий потенциал.

Shepelenko T. L.,Pinskaya A. L. Psycho-pedagogical conditions of readiness of students to creative professional and educational activitie.

The article reveals the essence and features of professional-pedagogical creativity, students' willingness to creative teaching activity, there is characterized its structure (psychological, theoretical, practical readiness), there are covered the psychological and pedagogical conditions of formation in the educational process of higher education.

Key words: readiness, creative teaching activities, co-creation, creative situation, creativity.

В умовах підвищення вимог суспільства до творчого потенціалу вищих навчальних закладів освіти інтенсивно здійснюється пошук i розроблення оптимального змісту, форм і методів підготовки педагогічних кадрів, готових до професійної творчості, яка сприяє самоактуалізації й самореалізаціі особистості. Нині творчий підхід до виконання професійних обов'язків одночасно $\epsilon$ i умовою, i показником інтенсивного оновлення педагогічної праці. Тому визначальною метою професійної підготовки студентів в умовах вищого навчального закладу повинно бути формування готовності майбутнього педагога до творчої педагогічної діяльності.

За останні десятиріччя в Україні було проведено багато досліджень, у яких розкриваються проблеми формування готовності до професійного саморозвитку (О. Пехота), інноваційної професійної діяльності (В. Шубинський), саморегуляції педагогічної діяльності (А. Ліненко). Предметом дослідження були питання структури готовності (Н. Кузьміна); показників готовності до педагогічної діяльності (О. Балл); змістових характеристик поняття готовності (В. Моляко). У 
наукових дослідженнях значне місце посідає розроблення психологічних концепцій готовності, яка розглядається як установка (Д. Узнадзе), психічний стан (Л. Кандибович), комплекс здібностей (Г. Балл).

Теоретичний аналіз свідчить, що попри значну увагу науковців до дослідження феномену готовності до найрізноманітніших аспектів педагогічної діяльності, формування у студентів готовності до творчої професійно-педагогічної діяльності не знайшла належного відображення в науковій літературі, а сучасна традиційна система навчального процесу у вищій школі недостатньо спрямована на розвиток творчості студентів.

Недостатня теоретична розробленість і практична значимість окресленої проблеми визначають пї актуальність.

Mema cmammi - розкрити сутність базових понять проблеми й охарактеризувати психолого-педагогічні умови формування готовності студентів до творчої педагогічної діяльності.

Розгляд означеної проблеми потребує визначення базових понять: «готовність», «професійна готовність», «творча педагогічна діяльність», «готовність до творчої педагогічної діяльності», «творчий потенціал».

Головними науковими підходами до окреслення категорії готовності є: психологічний (готовність розглядається як особистісна характеристика, що передбачає здатність до адаптації й саморегуляції поведінки й розвитку); педагогічний (готовність визначається як загальна характеристика розвитку, навчання i виховання особистості в галузі освіти відповідно до соціального замовлення); професійно-педагогічний (готовність визначається як характеристика результативності процесу професійної підготовки спеціалістів різних галузей знань).

3 точки зору А. Ліненко, готовність - це «цілісне утворення, яке характеризує емоційно-когнітивну і вольову мобілізаційність суб'єкта в момент його долучення до діяльності певного спрямування» [4, с. 56]. В. Моляко стверджує, що готовність - це складне особистісне утворення, багаторівнева та багатопланова система якостей і властивостей особистості, які у своїй сукупності дозволяють певному суб' єкту ефективно виконувати конкретну діяльність [7].

У психолого-педагогічних працях готовність до педагогічної діяльності розглядається з різних позицій. Так, О. Пєхота визначає готовність як складно структуроване утворення, яке забезпечує необхідні внутрішні умови задля успішного професійного саморозвитку майбутнього вчителя.

В. Шубинський розглядає готовність до педагогічної творчості як здатність учителя до виявлення закономірностей формування творчої особистості і створення умов для ії оптимального розвитку в навчально-виховному процесі.

3 позиції С. Литвиненко, «готовність до педагогічної діяльності становить інтегральне багаторівневе динамічне особистісне утворення, яке є результатом професійно-педагогічної підготовки» [5, с. 16].

Науковими дослідженнями Н. Кичук, А. Ліненко та інших доведено, що професійно-педагогічна готовність як якісне новоутворення формується тільки у процесі певної діяльності, що зумовлює необхідність визначення сутності й особливостей творчої педагогічної діяльності [2; 4].

Сучасна наука стверджує, що творчість- це діяльність, яка сприяє виникненню чогось якісно нового, відмінного неповторністю, оригінальністю й суспільно-історичною унікальністю. Маючи багато спільного 3 іншими видами творчості, педагогічна творчість характеризується своєрідністю, яка пов'язана як із 
характером процесу, так і 3 його результатом. Тому означене формулювання педагогічної творчості не може бути прийняте без певних уточнень і пояснень, що стосуються ії особливостей.

Педагогічна творчість розглядається як соціально й особистісно значуща діяльність педагога, спрямована на пошук, створення та використання нових, нестандартних (оригінальних) способів взаємодії з учнями задля спрямування їх поведінки й активності на засвоєння знань, умінь, навичок та самовдосконалення (А. Левчук), як здатність передбачати, емоційно переживати й оптимально розв'язувати завдяки творчій уяві завжди своєрідні проблемні ситуації шкільного життя (Н. Кичук), процес співтворчості (В. Кан-Калик, М. Никандров).

Аналіз психолого-педагогічної літератури 3 проблеми дослідження та розуміння дослідниками поняття «педагогічна творчість» надає підстави зробити певні узагальнення щодо поняття «готовність майбутнього педагога до педагогічної творчості».

Слід зазначити, що під час вивчення феномену готовності до творчої діяльності підходи психологів і педагогів мають певні розбіжності: психологи досліджують особливості й характер зв'язків між станом готовності та ефективною творчою діяльністю, а педагоги здійснюють дослідження умов, засобів і методів, які зумовлюють становлення і професійний розвиток майбутнього вчителя.

3. Левчук визначає готовність майбутнього вчителя до педагогічної творчості як здатність до творчої педагогічної діяльності, що зорієнтовані на професійну творчість і поєднує в собі потребу і здатність учителя реалізовувати свої сили і можливості в інтересах виховання творчої особистості учня й особистісної самореалізації [3].

К. Маркова розглядає готовність до педагогічної творчості у вузькому i широкому розумінні. У вузькому розумінні - це готовність до новаторства, готовність до пошуку і віднайдення принципово нових, раніше відсутніх і не відображених у літературі задач, засобів і прийомів діяльності (локальних - тих, що стосуються окремих методів і форм, або системних - тих, що уможливлюють усвідомлення нових, високоефективних систем навчання i виховання). У широкому розумінні «готовність до педагогічної творчості»- це здатність до відкриття вже відомого в науці і практичній діяльності поєднання методів, прийомів та умов їх використання, яка виникає в результаті сформованості дивергентного мислення [6, с. 57].

На думку М. Поташника, готовність майбутнього вчителя до педагогічної творчості - це готовність до діяльності, у результаті якої народжується дещо якісно нове, яке має риси неповторюваності, оригінальності та загальноісторичної унікальності [8]. 3 точки зору В. Кан-Калика, готовність до педагогічної творчості це готовність до діяльності, спрямованої на постійне розв'язання нескінченного ряду навчально-виховних задач під час регулярних змін обставин. Під час такої діяльності педагогом розробляються і втілюються у процес спілкування з учнями оптимальні, органічні методи і прийоми творчої взаємодії [1, с. 127].

Зауважимо, що наявні розбіжності у визначенні сутності готовності до творчої педагогічної діяльності зумовлені передусім предметом дослідження науковців, різним контекстом розгляду проблеми.

Виходячи із здійсненого аналізу психолого-педагогічної літератури готовність студента до педагогічної творчості ми розглядаємо як його потенційну здатність до здійснення творчої педагогічної діяльності, яка формується у процесі спеціально організованої професійної підготовки і зумовлена рівнем розвитку професійних і особистісних якостей майбутнього педагога, які сприяють успішній творчій педагогічній діяльності. 
Проблема формування готовності до творчої професійно-педагогічної діяльності передбачає необхідність окреслення структури цього феномену. Визначаючи компонентний зміст структури, більшість науковців основними компонентами вважає такі: психологічна готовність- особистісно-мотиваційна: особистісні якості; професійна спрямованість, потреба у творчій діяльності; теоретична готовність - система знань щодо творчої педагогічної діяльності, способів та форм їх упровадження у професійну діяльність тощо; практична готовність - сукупність умінь організовувати творчу педагогічну діяльність [3; 4; 7].

Виходячи 3 вище викладеного, можемо стверджувати, що формування готовності студентів до педагогічної творчості передбачає створення в навчальновиховному процесі таких психолого-педагогічних умов, які забезпечують особистісно зорієнтовану розвивальну взаємодію в системі «викладач - студент», «студент - студент».

Теоретичний аналіз і практика дозволили виокремити такі психологопедагогічні умови детермінації ефективного формування готовності студентів до творчої педагогічної діяльності:

- евристична спрямованість процесу навчання;

- організація особистісно зорієнтованого навчання;

- гармонізація інтелектуального й емоційного аспектів навчання.

Як творча праця, педагогічна діяльність у змістовому аспекті зберігає загальну логіку творчого процесу. Але у процесуальному - вона має низку специфічних характеристик. Так як суб'єктом педагогічної творчості $\epsilon$ особистість, педагог реалізує свій особистісний і професійний творчий потенціал засобом творення цієї особистості, а розвиток його творчого потенціалу зумовлений розвитком творчого потенціалу студента. Тому особливістю педагогічної творчості $\epsilon$ те, що вона становить процес співтворчості [3; 7].

Залучення до співтворчості потребує організації навчально-творчої діяльності, під якою С. Сисоєва розуміє таку діяльність, яка сприяє подальшому розвитку у студентів внутрішніх передумов до творчості, тобто креативного ядра особистості, яке забезпечує саму здатність людини до творчості та рівень подальших творчих досягнень. Для організації навчально-творчої діяльності «необхідна загальна евристична спрямованість процесу навчання» [1, с. 54].

Для цього, на думку В. Кан-Калика, М. Никандрова, необхідно вивести за можливості кожен елемент педагогічної діяльності на евристичний рівень. Визначальним чинником організації евристично спрямованого навчання виступає творча ситуація [1]. Творча ситуація, з точки зору М. Поташника, - це ситуація, яка потребує розв'язання певної суперечності і може бути створена у процесі розв'язання пошуково-творчих задач, розв'язання навчальних проблем, критичного аналізу літератури, участі в навчально-експериментальній та дослідницькій діяльності [8].

Продуктивне розв'язання творчих ситуацій необхідно організовувати відповідно до лінії створення «індивідуальної зони - ситуації творчого розвитку кожного учня» [1]. Задля створення індивідуальної зони творчого розвитку студента педагогу необхідно урахувати індивідуально-психологічні особливості кожного, що надає змогу загальні педагогічні задачі, щоб вони були ними сприйняті, співвідносити з логікою їхньої пізнавальної діяльності.

У процесі розв'язання творчих педагогічних ситуацій, студенти вчаться виокремлювати істотні ознаки педагогічних явищ, зіставляти факти, виказувати найбільш імовірні припущення, обирати ефективні способи розв'язку. В умовах евристично 
спрямованого навчання кожне заняття стає для студентів «школою мислення», яка перетворює їх зі свідків на активних учасників наукового пошуку, стимулює пізнавальну діяльність, учить творчо підходити до розв'язання професійних проблем.

Своєрідність педагогічної творчості полягає також у тому, що вона реалізується не тільки в системі «викладач - студент», а і в системі «студент студент», тобто в колективній діяльності. Тому викладачу необхідно, щоб кожна творча задача завжди була зорієнтованою на співтворчість, тобто щоб процес іiі розв'язання передбачав не тільки логіку дій «викладач - студент», а і логіку дій «викладач - група», «студент - студент».

На основі колективної співтворчості, коли дії кожного студента певною мірою залежать від дій інших, коли всі учасники впевнені в можливості досягнення спільної мети, збільшуються можливості для сприйняття, оцінки й перероблення навчальної інформації, проникнення у іiї зміст, який стає предметом роздумів, що спонукає до обміну думками, діями i створює можливості управління індивідуальними діями відповідно до форми взаємодії, активізує творче мислення студентів, формує їхню творчу активність.

Формування готовності майбутнього педагога професійного навчання до створення індивідуальної зони творчого розвитку кожного учня потребує вдосконалення навчального процесу в аспекті переходу від авторитарних засад у підготовці майбутніх фахівців до їх підготовки на засадах рівноправності викладача і студента. У зв'язку з цим посилюється необхідність використання в навчальному процесі різних освітніх закладів новітніх технологій навчання, однією 3 яких є особистісно зорієнтоване навчання.

Особистісно зорієнтоване навчання передбачає передусім виявлення особливостей особистості як суб'єкта, як самобутності й самоцінності і побудову педагогічних упливів 3 максимальною опорою на іiі досвід. Є. Бондаревська зазначає, що основою особистісно зорієнтованого навчання $є$ визнання студента активним учасником навчально-виховного процесу, здатним здійснювати на нього суттєвий уплив, перебудовувати його відповідно до потреб своєї особистості.

I. Якиманська під особистісно зорієнтованим навчанням розуміє таке навчання, де провідною $є$ особистість студента, іiі самоцінність. Суб'єктивний досвід спочатку розкривається, а потім узгоджується зі змістом навчання. За цих умов виникає необхідність розподілити традиційно недиференційований навчальновиховний процес на «навчання» й «учіння» із пріоритетом процесу учіння як індивідуально значущої творчої діяльності [10].

Ми поділяємо думку автора стосовно того, що особистісно зорієнтоване навчання передбачає право студента на процес «творення самого себе»у процесі пізнання шляхом оволодіння способами навчальної діяльності, спрямованої на формування у студента не стільки типового, скільки яскраво вираженого індивідуального, яке дозволяє особистості стати і залишатися собою в соціумі, що швидко змінюється. Технологія особистісно зорієнтованого навчання грунтується на зіставленні навчання як нормативної діяльності й учіння як індивідуально значущої діяльності окремого студента. Ї̈̈ зміст, методи, прийоми спрямовані передусім на те, щоб розкрити і використати суб' єктивний досвід кожного студента, допомогти становленню особистісно значущих способів пізнання шляхом організації цілісної навчально-пізнавальної діяльності.

Найважливішими чинниками особистісно зорієнтованого навчального процесу $\epsilon$ ті, що розвивають індивідуальність студента, створюють умови задля його 
саморозвитку та самовираження. Виходячи 3 викладеного вище, можна стверджувати, що метою особистісно зорієнтованого навчання $\epsilon$ розвиток індивідуально-творчих пізнавальних здібностей кожного студента.

Вияву особистісних творчих здібностей в освітньому процесі сприяють спеціально створені особистісно зорієнтовані ситуації (навчальні, пізнавальні, життєві), які грунтуються на ідеї реалізації: життєвого контексту, діалогічності, рольової взаємодії іiі учасників. Технологія здійснення особистісного підходу, на думку О. Бондаревської, передбачає використання методів і прийомів, які б відповідали таким вимогам: діалогічність, діяльнісно-творчий характер, надання студентам свободи задля прийняття рішень, творчості, вибору змісту і способів учіння. Такий арсенал передбачає діалог, ігрові методи і прийоми, застосування методів діагностування і самодіагностування, створення ситуації успіху, ситуацій індивідуального й колективного вибору. Наявність у педагога уявлень про сутність, побудову i структуру особистісно зорієнтованого підходу дозволяє йому цілеспрямовано й ефективно моделювати і будувати відповідно до окресленої орієнтації конкретні навчальні заняття.

Шлях до творчості в кожного студента індивідуальний. Це виявляється в тому, що кожен $з$ різною глибиною розуміє і з різним рівнем творчості справляється 3 навчальними завданнями.

Навчання може стати цікавою, захоплюючою творчою справою тільки за умови доброзичливого ставлення викладача до студентів, поваги до їх гідності, що неможливе без створення на заняттях позитивного психологічного клімату, що виражається в довірі між студентами і викладачами, дозволяє кожному відчути власну значущість і впевненість у собі, сприяє створенню у навчальному процесі ситуації успіху як переживання почуття радості від досягнутого, яке стимулює ініціативу, творчу активність студентів, формує у них мотивацію досягнень.

Тому формування готовності до творчої діяльності неможливе без створення на заняттях ситуації успіху, яка сприяє формуванню у студентів таких якостей, як оптимізм, позитивна професійна Я-концепція і становить умову реалізації їх творчих можливостей.

Засобом створення ситуації успіху $є$ гармонізація інтелектуального й емоційного аспектів творчої діяльності. Досвід переконливо свідчить, що сучасна вища школа зосереджує увагу переважно на інтелектуальному чиннику навчання без урахування емоційного компонента. Психолого-педагогічними дослідженнями доведено, що засвоєння знань потребує не тільки їх осмислення і розуміння, але й переживання знань. Тому в навчальному процесі необхідно пробуджувати у студентів «почуття здивування та радості відкриття» (В. Сухомлинський), що неможливе без формування емоційної сприйнятливості, що потребує взаємозв'язку між думкою й емоціями На думку С. Рубінштейна, емоції виражають стан суб'єкта і його ставлення до об'єкта і вирізняються полярністю, тобто можуть бути як позитивними, так і негативними [9]. Виходячи з цього, можемо стверджувати, що через емоції виражається ставлення студента до процесу навчання, а тому стосовно творчої діяльності емоції також можуть мати як пасивну роль, так і роль активного засобу формування готовності до творчої діяльності.

Спеціальні дослідження і практика свідчать, що студенти виявляють нездатність установлювати смислові зв'язки між подіями й власними переживаннями. Це $\epsilon$ результатом того, що в навчальному процесі вищої школи недостатньо використовується «мова емоцій». Бідність і недиференційованість «емоційного 
словника» студентів і викладачів призводить до формування особливого типу мислення, у якому обмежено представлений їхній внутрішній світ, що негативно позначається на творчому розвитку особистості. Водночас практика свідчить, що творчий розвиток особистості визначається значною мірою їі емоційним відгуком на навчальну інформацію і процес навчання. Як стверджує С. Рубінштейн, «самі емоції людини, становлять єдність емоційного й інтелектуального, як і пізнавальні процеси зазвичай створюють єдність інтелектуального й емоційного» [9, с. 352].

Емоційна забарвленість навчальної діяльності позитивно впливає на творчий характер пізнавальних процесів студентів, упевненість у своїх силах, переживання незвичності прийнятого правильного рішення, що сприяє більш швидкому i міцному засвоєнню знань. Негативні емоції (страх, незадоволеність собою та викладачем, образа, напруженість, невпевненість та ін.) призводять до формування байдужого ставлення до навчання, гальмують внутрішне прагнення творити, що порушує пізнавально-емоційну цілісність особистості

Тільки за умови гармонізації інтелектуальних та емоційних зусиль студента можна чекати позитивних результатів у його підготовці до педагогічної творчості. Позитивне емоційне ставлення до навчання робить його особистісно значущим i стимулює формування пізнавальних інтересів, потреб у творчій самореалізації. Дослідження науковців показали, що емоції (подив, сумнів, успіх, радість тощо) активізують процеси творчого мислення, стимулюють пошук, пробуджують у людини бажання віднаходити оптимальні засоби творчого розв'язання проблем.

Отже, формування готовності майбутніх педагогів професійного навчання до творчої педагогічної діяльності вимагає організації навчального процесу на основі таких психолого-педагогічних умов: організації евристично спрямованого навчання, використання технології особистісно зорієнтованого навчання, гармонізації інтелектуального й емоційного аспектів навчання. Визначені й обгрунтовані педагогічні умови становлять сукупність взаємопов'язаних компонентів, кожний із яких є об'єктом цілеспрямованого формування.

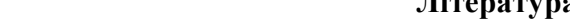

Література

Н. Д. Никандров. - М. : Педагогика, 1990. - 144 с. 2. Кичук Н. В. Формування творчої особистості вчителя: [монографія] / Н. В Кичук. - К. : Вища школа, 1994. - 156 с. 3. Левчук 3. С. Формирование готовности к профессиональному творчеству у студентов педвуза: автореф. дис. на соискание ученой степени канд. пед. наук: спец. 13.00.04. / 3. С. Левчук. - Минск, 1992. - 19 с. 4. Линенко А. Ф. Теория и практика формирования готовности студентов педагогических вузов к профессиональной деятельности: дис. ... доктора пед. наук: 13.00.01, 13.00.04 / Линенко А. Ф. - К., 1996. 378 с. 5. Литвиненко С. А. Теоретико-методологічні засади підготовки майбутніх учителів початкових класів до соціально-педагогічної діяльності: автореф. дис. на здобуття наук. ступеня доктора пед. наук / С. А. Литвиненко. - К., 2005. - 40 с. 6. Маркова А. К. Психология профессионализма / А. К. Маркова - М., 1996. - 312 с. 7. Моляко В. О. Психологічна готовність до творчої праці / В. О. Моляко. - К. : Знання, 1989. - 256 с. 8. Поташник М. М. Педагогическое творчество: проблемы развития и опыт: [пособие для учителя]/ М. М. Поташник- К. : Рад. школа, 1988. - 187 с. 9. Рубинштейн С. Л. Проблемы общей психологии / С. Л. Рубинштейн. - М. : Педагогика, 1973. - 423 с. 10. Якиманська І. С. Розробка технологій особистісно орієнтованого навчання / І. С. Якиманська // Питання психології. - 1995. - № 2. - С. 31-54. 